\title{
How Do Staggered Boards Affect Shareholder Value? Evidence from a Natural Experiment
}

\section{Citation}

Cohen, Alma, and Charles C.Y. Wang. "How Do Staggered Boards Affect Shareholder Value? Evidence from a Natural Experiment." Journal of Financial Economics 110, no. 3 (December 2013): 627-641.

\section{Published Version}

http://www.sciencedirect.com/science/article/pii/S0304405X13002067

\section{Permanent link}

http://nrs.harvard.edu/urn-3:HUL.InstRepos:28538428

\section{Terms of Use}

This article was downloaded from Harvard University's DASH repository, and is made available under the terms and conditions applicable to Open Access Policy Articles, as set forth at http:// nrs.harvard.edu/urn-3:HUL.InstRepos:dash.current.terms-of-use\#OAP

\section{Share Your Story}

The Harvard community has made this article openly available.

Please share how this access benefits you. Submit a story.

Accessibility 


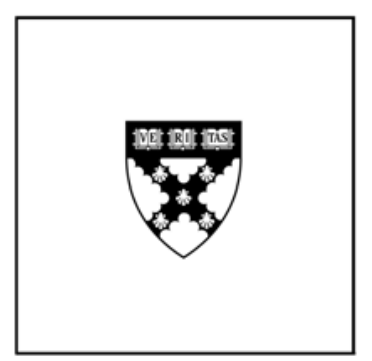

\title{
How Do Staggered Boards Affect Shareholder Value? Evidence from a Natural Experiment
}

\author{
Alma Cohen \\ Charles C.Y. Wang
}

\section{Working Paper}

13-068

May 17, 2013 


\title{
How Do Staggered Boards Affect Shareholder Value? Evidence from a Natural Experiment
}

\author{
Alma Cohen \\ Tel-Aviv University, Harvard Law School, and National Bureau of Economic Research \\ Charles C.Y. Wang * \\ Harvard Business School
}

May 2013

\begin{abstract}
The well-established negative correlation between staggered boards (SBs) and firm value could be due to SBs leading to lower value or a reflection of low-value firms' greater propensity to maintain SBs. We analyze the causal question using a natural experiment involving two Delaware court rulings-separated by several weeks and going in opposite directions-that affected the antitakeover force of SBs. We contribute to the long-standing debate on staggered boards by documenting empirical evidence consistent with the market viewing SBs as leading to lower firm value for the affected firms.
\end{abstract}

Keywords: Corporate governance, staggered board, takeover defense, antitakeover provision, proxy fight, Tobin's Q, firm value, agency cost, Delaware, chancery court, Airgas.

JEL: G30, G34, K22

${ }^{*}$ Corresponding email address: charles.cy.wang@hbs.edu. For helpful comments and suggestions, we are grateful to Steven Davidoff, Jeff Gordon, Guhan Subramanian, Nick Bloom, Dirk Jenter, Michael Klausner, David Larcker, Charles Lee, Daniel Malter, Suraj Srnivasan, participants in a Harvard workshop, a Northwestern workshop, and the FARS conference, and, especially, Lucian Bebchuk. We also thank Kyle Thomas for his research assistance. This paper draws on an earlier discussion paper on the subject, which we coauthored with Lucian Bebchuk, but uses different empirical methodology. 


\section{Introduction}

Governance provisions that weaken shareholder rights and insulate directors from removal are now well known to be negatively correlated with firm value (Gompers, Ishii, and Metrick, 2003). This correlation is partly driven by the negative association between firm value and staggered board provisions, which prevent shareholders from removing a majority of directors in any given shareholder meeting (Bebchuk and Cohen, 2005; Bebchuk, Cohen, and Ferrell, 2009). Such correlation, however, may not imply causation but could reflect the greater propensity of low-value firms to maintain such provisions. In this paper, we seek to contribute to understanding the causal question by studying two natural experiments: two court rulings that affected, for a subset of Delaware firms, the extent to which staggered boards can impede shareholders seeking to replace a majority of directors. We find evidence consistent with market participants viewing the antitakeover force of staggered boards as bringing about - and not merely reflecting - reduced shareholder value.

Our findings contribute to the long-standing debate on staggered boards by providing causal, rather than just correlational, empirical evidence on the effect of weakening staggered boards on shareholder value. Certain institutional investors have over time become increasingly opposed to staggered boards. The Council of Institutional Investors ${ }^{1}$; major institutional investors such as American Funds, BlackRock, CalPERS, Fidelity, TIAACREF, and Vanguard ${ }^{2}$ and the two leading proxy advisors, ISS and Glass Lewis ${ }^{3}$ all have policies favoring both the annual election of all directors and board de-staggering proposals. As a result, many companies have chosen to eliminate staggered boards in

\footnotetext{
${ }^{1}$ Council of Institutional Investors, Corporate Governance Policies, p. 3.

${ }^{2}$ American Funds, Proxy Voting Procedures and Principles, p. 3; BlackRock, Proxy Voting Guidelines for U.S. Securities, p. 6; California Public Employees' Retirement System, Global Principles of Accountable Corporate Governance, p. 17; Fidelity Investments, Corporate Governance and Proxy Guidelines, p. 11; TIAA-CREF, Policy Statement on Corporate Governance, p. 31; Vanguard, Vanguard's Proxy Voting Guidelines, p. 2.

${ }^{3}$ RiskMetrics Group, 2010 U.S. Proxy Voting Guidelines Summary, p. 18.
} 
recent years. According to FactSet Research Systems, the number of Standard \& Poor's 500 companies with staggered boards declined by more than $50 \%$ from 2000 to 2012 . Still, many companies continue to maintain staggered boards and argue that such provisions enhance rather than reduce shareholder value. ${ }^{4}$ As of today, of the more than 3,000 publicly traded companies whose takeover defenses are tracked by FactSet Research Systems, over half still have a staggered board.

The theoretical literature cannot fully resolve the ongoing debate as it identifies both costs and benefits of staggered boards (and of takeover defenses more generally). On the one hand, insulating incumbent directors from the disciplinary threat of removal may enable those directors (as well as the managers they oversee) to deviate from the interests of shareholders by shirking, empire-building, and extracting private benefits (Manne, 1965); moreover, such insulation may allow self-interested directors and managers to block acquisition attempts (Easterbrook and Fischel, 1981) or discourage potential acquirers from making offers (Grossman and Hart, 1980) that would have been beneficial to shareholders.

On the other hand, protecting directors and managers from control contests might enable them to focus on creating long-run shareholder value and avoid inefficient shorttermism (Stein, 1988). Furthermore, staggered boards may also improve the bargaining position of target firms during takeover attempts, allowing target firm management to extract greater acquisition premiums (Stulz, 1988). Beyond the takeover contexts, it is argued that staggered boards can produce benefits by securing stability and continuity in board composition, but, at the same time, can produce costs by preventing shareholders from recording their views on the performance of individual directors each year. Given the ambiguity from a theoretical standpoint, empirical evidence is useful in advancing the debate.

\footnotetext{
${ }^{4}$ For examples of statements of boards of directors in opposition to shareholder proposals in favor of board de-staggering brought to a vote in 2010 annual meetings, see the 2010 proxy statements of Abercrombie \& Fitch Co.; Bancorp South, Inc.; and Hospitality Properties Trust.
} 
To contribute to the empirical assessment of the value implication of staggered boards, we use a quasi-experimental research design based on two Delaware court rulings. In particular, we focus on the Chancery Court and Supreme Court rulings of October 8, 2010 and November 23, 2010, respectively, in the takeover battle between Airgas Inc. (Airgas) and Air Products and Chemicals, Inc. (Air Products). The rulings focused on the permissibility of shareholder-adopted bylaw amendments that substantially weaken the antitakeover force of staggered boards, arising from Air Products' battle to take over Airgas. The Delaware Chancery Court initially ruled that such shareholder-adopted bylaw amendments are permissible but the Delaware Supreme Court subsequently reversed and held such measures to be invalid.

We examine the cross-section of stock returns surrounding the announcements of the rulings and compare the returns of the set of companies that were most affected by the rulings to the returns of companies that were not impacted. We estimate the average treatment effect for the treated group of firms using standard ordinary least squares regressions as well as propensity score matching methods. We also employ placebo tests and simulation methods to rule out alternative explanations and assess the significance of our estimated treatment effects. Overall, our evidence is consistent with the hypothesis that the value of the affected companies was increased by the initial ruling weakening the antitakeover force of staggered boards and was decreased by the ruling's subsequent reversal. We also find that these pairs of relative market responses are unlikely to arise from random sampling variation.

Our findings that the weakening of the antitakeover force of staggered boards, on average, improves firm value are consistent with the support among certain institutional investors for proposals to repeal staggered boards. These findings are also consistent with the view that the continued de-staggering of boards - an ongoing process over the past decade - can be expected to produce benefits for shareholders. However, interpretation 
of our results is subject to the following two caveats. First, since we estimate the average treatment effect of staggered boards for the affected firms in our sample, we cannot rule out the possibility that staggered boards might have heterogeneous effects. Future empirical work might consider how the impact of staggered boards on firm value varies for different types of firm. For example, it will be useful towards understanding the valueimplications of staggered boards (and of takeover defenses in general) to empirically identify some subsets of firms for which the effect is zero or positive. Second, our setting takes as given the current Delaware rules allowing for the unhindered use of defensive tactics such as poison pills to deter unwanted takeover bids. Thus, our findings do not speak to the question of whether having annual elections can be expected to produce greater shareholder value than having staggered boards with specific limits on takeover defenses.

Our work seeks to contribute to the existing body of empirical work on staggered boards, which have been largely correlational, by providing causal evidence on the impact of weakening staggered boards on shareholder value. Bebchuk, Coates, and Subramanian (2002) find that takeover targets with a staggered board are associated with lower gains to shareholders following the receipt of a tender offer. Bebchuk and Cohen (2005) document that staggered boards are associated with lower firm valuation as proxied by Tobin's Q. Masulis, Wang, and Xie (2007) find that firms with staggered boards are associated with value-decreasing acquisition decisions, while Faleye (2007) reports that staggered boards are associated with lower sensitivity of compensation to firm performance and lower sensitivity of CEO turnover to firm performance. Bates, Becher, and Lemmon (2008) report that staggered boards have a positive correlation with higher takeover premiums but also note that staggered boards are associated with a lower likelihood of acquisition and confirm, consistent with earlier work, that staggered boards are associated overall with lower firm valuation. We seek to contribute to this body of work by using a quasi- 
experimental setting to study whether the identified correlation between staggered boards and lower firm value is at least partly driven by staggered boards lowering firm value. ${ }^{5}$

Our study also builds on the large event study literature that uses stock price reactions to study the wealth effects of regulatory changes, beginning with Schwert (1981). ${ }^{6}$ The challenges facing event studies of governance changes are now well understood. Event studies focusing on governance changes adopted by companies bundle together the market's assessment of the changes with the market's inferences concerning private information that might have led management to make such changes (e.g., Binder, 1985; Coates, 2000). In addition, events focusing on the legislative adoption of new arrangements (e.g., Karpoff and Malatesta, 1989) might face the difficulty that, at the time of adoption, market participants might not have accumulated sufficient experience with the consequences of the newly adopted arrangements.

The pair of rulings on which our study focuses provides a good quasi-experimental setting with advantages over standard event studies. First, there are relatively clearly defined groups of affected and unaffected firms, with a firm's treatment status depending on whether its annual shareholder meeting took place late or early in the calendar year.

\footnotetext{
${ }^{5}$ Bebchuk and Cohen (2005) explore the causality issue by using staggered boards in 1990 as an instrument. While they find evidence consistent with staggered boards having a causal effect, that evidence is offered as being merely suggestive. We also wish to note the results of Guo, Kruse, and Nohel (2008), who find positive stock market reactions to announcements by companies on plans to de-stagger. While the results of these authors are consistent with ours, it is difficult to draw causal inferences from their findings because management decisions to de-stagger are unlikely to be random. Instead, they tend to be made by managements that anticipate improvements in firm value which would make them less vulnerable to a control contest in any event and may thus be a signal to the market about management's positive inside assessment. An earlier paper by Bhagat and Jefferis (1991), using data from the 1980s, during which antitakeover amendments often passed, studied the returns accompanying the announcements of such amendments (antitakeover amendments in general, not only those resulting in a staggered board).

${ }^{6}$ See MacKinlay (1997) for a review of the application of event studies to economics and finance, and Bhagat and Romano (2002) for a survey of such applications in corporate law. We add to this work using event studies to study the effects of governance arrangements. Recent contributions to this literature include the work of Chhaochharia and Grinstein (2007) and Hochberg, Sapienza, and Vissing-Jørgensen (2009), who use stock returns to study the effects of the Sarbanes-Oxley Act, and Larcker, Ormazabal, and Taylor (2011) and Becker, Bergstresser, and Subramanian (2012), who analyze stock returns to study the expected effects of proxy access reform.
} 
Second, whether a shareholder meeting took place late or early in the year was predetermined by the firm's historical fiscal year-end month and was therefore independent of the rulings. Third, these exogenous changes took place at precise moments in time and were not fully anticipated, giving rise to a treatment outcome to be studied. Fourth, the changes concerned an arrangement - staggered boards - with whose consequences market participants have had a great deal of experience for two decades. Finally, we benefit from the fact that we have two events, each affecting the same set of companies but in opposite directions.

The remainder of this paper is organized as follows. Section 2 discusses the relevant institutional background, including the Delaware Chancery and Supreme Court rulings that are the focus of our study. ${ }^{7}$ Section 3 describes our data and provides summary statistics. Section 4 shows that the stock returns accompanying the two rulings are consistent with the markets viewing staggered boards as lowering firm value. Section 5 concludes the paper.

\section{Staggered Boards and the Airgas Ruling}

\subsection{Staggered Boards}

A company may have a unitary or a staggered board. In a unitary board structure, all directors stand for election at each annual meeting. By contrast, in a staggered board structure, directors are divided into (typically three) separate classes serving staggered terms, with only one class of directors up for reelection at a given annual shareholder meeting. Because directors on a typical staggered board serve a term of approximately three years, a staggered board structure gives incumbent directors substantial protection from removal or attempts to gain control via either a proxy fight or a takeover bid.

\footnotetext{
${ }^{7}$ This description of the institutional background draws on the work of Bebchuk, Cohen, and Wang (2011).
} 
In a proxy fight over a company with a staggered board, a challenger cannot gain control of the board in one annual meeting but would need to win shareholder votes in two consecutive shareholder meetings. Thus, even a competing team that is viewed as superior by shareholders would face a substantial delay in its attempt to gain control. Furthermore, the prospect of a board that is bitterly split in the period between the two shareholder meetings might discourage some shareholders from voting for a challenger they would have supported if a clean-cut transition were possible.

Staggered boards also provide substantial protection against hostile bidders because, following the development of the poison pill, a hostile bidder can prevail over incumbent opposition only by getting shareholders to replace the majority of the directors. During the 1980s and early 1990s, U.S. law developed to allow incumbents to adopt and maintain poison pill plans that, as long as they are in place, make it prohibitively expensive for a bidder to purchase a large block. As a result, the only route left for hostile bidders is to put an attractive offer on the table and persuade shareholders to replace the incumbents with a slate of directors receptive to the acquisition bid, a slate typically nominated by the bidder itself. Once elected, such a slate of directors would redeem the poison pill and make the acquisition possible.

Thus, a hostile takeover requires a ballot box replacement of a majority of directors and is hence hindered by the presence of a staggered board. With a staggered board, no matter how attractive a bidder's offer is, the bidder would have to win in two consecutive annual meetings. The evidence indicates that a takeover target is substantially more likely to be able to fend off a hostile takeover bid and remain independent when its board is staggered (Bebchuk, Coates, and Subramanian, 2002). 


\subsection{The Airgas Bylaw}

\subsubsection{The Bylaw}

Our quasi-experiment is based on a well-followed takeover battle involving the attempt by Air Products to gain control over Airgas. A good account of the battle can be obtained from a series of "Deal Professor" columns written by Professor Steven Davidoff for New York Times website. ${ }^{8}$ In October 2009, Air Products expressed an interest in acquiring Airgas. Air Products made three offers over the following four months, which were all rejected by Airgas's board of directors. In February 2010, Airgas rejected Air Products' $\$ 5$ billion, all-cash tender offer to acquire $100 \%$ of Airgas's shares. ${ }^{9}$

Facing the opposition of the Airgas board, Air Products proceeded to a proxy fight at the Airgas shareholder meeting in September 2010. Because Airgas has a staggered board consisting of three classes, only one-third of its nine directors came up for reelection at the meeting. With a majority of Airgas's shareholders seemingly supportive of this acquisition attempt, Air Products was able to replace the directors up for reelection in the September 2010 shareholder meeting with three individuals whom it had nominated.

In the ordinary course of events, Air Products would have been expected to wait an

\footnotetext{
${ }^{8}$ Steven M. Davidoff, "The Way Forward for Airgas," New York Times website, March 19, 2010, http: //dealbook.nytimes.com/2010/03/19/the-way-forward-for-airgas; Davidoff, "The Air ProductsAirgas Battle Heats Up," New York Times website, May 14, 2010, http://dealbook.nytimes.com/ 2010/05/14/the-air-products-airgas-battle-heats-up; Davidoff, "Airgas Rolls the Dice in Proxy Fight," New York Times website, August 30, 2010, http://dealbook.nytimes.com/2010/08/30/ airgas-rolls-the-dice-in-proxy-fight; Davidoff, "Airgas's Novel Question," New York Times website, September 1, 2010, http://dealbook.nytimes.com/2010/09/01/airgas-novel-question; Davidoff, "After Losing Vote, What's Next for Airgas?" New York Times website, September 16, 2010, http://dealbook.nytimes.com/2010/09/16/after-losing-vote-whats-next-for-airgas; Davidoff, "Air Products Wins Round in Battle with Airgas," New York Times website, October 8, 2010, http: //dealbook.nytimes.com/2010/10/08/air-products-wins-round-in-battle-with-airgas; Davidoff, "The Dwindling Options for Airgas," New York Times website, October 11, 2010, http://dealbook. nytimes.com/2010/10/11/the-dwindling-options-for-airgas; Davidoff, "Airgas's Strategic Blink," New York Times website, October 28, 2010, New York Times website, October 28, 2010, http: //dealbook.nytimes.com/2010/10/28/airgass-strategic-blink.

${ }^{9}$ On February 11, Air Products announced an all-cash tender offer at that price for $100 \%$ of Airgas shares at $\$ 60$ per share, which was again rejected by Airgas. Air Products continued to raise its bids over the next few months, each being met with cool rejection. On July 8, it increased its offer to $\$ 63.50$ per share and on September 6, it raised its bid to $\$ 65.50$ per share.
} 
additional year for the opportunity to replace another third of Airgas's directors and pave the way for acquisition. ${ }^{10}$ In this case, however, Air Products made a novel move, which seems to have been first suggested in one of Professor Davidoff's "Deal Professor" columns. ${ }^{11}$ At the September 2010 annual meeting, Air Products obtained majority shareholder approval for a new shareholder-adopted bylaw provision (the Airgas bylaw), which specified that the next annual meeting would be held on January 18, 2011, a mere four months after the September 2010 annual meeting.

Airgas turned to the Delaware Chancery Court, seeking to invalidate the bylaw. Airgas argued that, by shortening the directors' terms, such a bylaw is inconsistent with the provision in the Airgas charter that established the staggered board structure. Airgas warned that interpreting the standard language in its charter as permitting shareholders to adopt bylaws such as the Airgas bylaw would dilute the significance of having a staggered board in many companies. In response, Air Products argued that the charter provision establishing a staggered board should be interpreted as requiring only that one-third of the directors come up for election in each calendar year's annual meeting, without limiting the ability of bylaws to specify the time during the calendar year in which the annual meeting will take place.

\subsubsection{The Bylaw and the Antitakeover Force of Staggered Boards}

The litigation attracted significant attention, which was partly due to its implications for other publicly traded companies with a staggered board and an annual meeting ordinarily taking place later in the calendar year. ${ }^{12}$ To the extent that bylaws such as the

\footnotetext{
${ }^{10}$ Boards of Delaware companies are not permitted to delay the annual meeting beyond thirteen months after the preceding annual meeting.

${ }^{11}$ Davidoff, "The Way Forward for Airgas."

${ }^{12}$ Because Delaware law requires firms to have an annual meeting in each calendar year, a late meeting date refers throughout the paper to lateness within the calendar year (even for the small fraction of firms whose fiscal year for accounting purposes differs from the calendar year). As discussed in Section 4.1 below, prior to the Airgas battle, the choice of the annual meeting timing was generally not viewed as relevant for corporate control purposes and was made on the basis of various historical and logistical
} 
Airgas bylaw are permitted, the antitakeover force of these companies' staggered boards would be weakened, as shareholders favoring a premium offer blocked by incumbent directors would be able to pass such a bylaw and shorten the delay required for replacing a majority of the board. ${ }^{13}$ Following the Chancery Court ruling permitting such bylaws, the "Deal Professor" column stated that the opinion "blows a hole in the defenses of many companies with staggered boards" and that these companies "will have to live with the fact that a staggered board can be weakened by forcing a subsequent annual meeting to occur much sooner than people thought." Conversely, to the extent that such bylaws are impermissible, as the Delaware Supreme Court ultimately held, the antitakeover force of these companies' staggered boards will remain intact and the "hole in the defenses" will be filled. ${ }^{14}$

Note that validation of the Airgas bylaw would have weakened, but not fully eliminated, the antitakeover force of staggered boards. The use of such a bylaw could shorten the delay in replacing a majority of the directors but not eliminate this delay altogether. Thus, any effects we identify empirically are expected to understate the magnitude of the effect of the antitakeover force of staggered boards on firm value.

Note further that, if the Airgas bylaw were validated, firms with late-year annual meetings could potentially and preemptively amend their bylaws to move the meeting to the beginning of the year. Because Delaware law requires firms to have an annual meeting in each calendar year, firms makings such a change would substantially shorten the tenure of their current directors as well as bear the costs of holding two annual meetings, each considerations.

${ }^{13}$ For firms with cumulative voting and a significant insider block, the analysis would have to take into account the ability of the insiders to use cumulative voting to secure some representation on the board. In such firms, cumulative voting could thus moderate the extent to which the adoption of an Airgas bylaw would weaken the antitakeover force of a staggered board. In any event, while cumulative voting used to have significant presence, this is no longer the case. In the SharkRepellent universe from which we obtained our data, the percentage of firms with cumulative voting in our sample period is $3.9 \%$ for Delaware firms in general and $2.2 \%$ for Delaware firms with staggered boards.

${ }^{14}$ Davidoff, "Air Products Wins Round in Battle with Airgas." 
with its own proxy statement and voting on a range of issues, only a few months apart.

To illustrate, consider a firm that will have its annual meeting in September 2013 and is scheduled to have its subsequent annual meeting in September 2014. Because the firm is required to have an annual meeting in 2014, switching to a January meeting date would mean replacing the September 2014 meeting with a meeting in January 2014, just four month after the preceding annual meeting. As we argue above, because of the potential costs involved for the directors as well as for the company, such a maneuver should not have been generally expected following a validation of the Airgas bylaw. However, to the extent that some firms could have been expected by market participants to engage in such a maneuver following the validation of the Airgas bylaw, this would further increase the extent to which any empirically identified effects in our setting understate the market's assessment of the magnitude of the effect of staggered boards on firm value.

\subsection{The October 8 Chancery Court Ruling}

As is common in the courts of Delaware, the litigation over the permissibility of the Airgas bylaw proceeded quickly, with a final hearing taking place in the Delaware Court of Chancery on Friday, October 8, 2010. That evening, after the close of the stock market, Chancellor Chandler issued an opinion that sided with Air Products and approved the legality of the Airgas bylaw. ${ }^{15}$ Chandler concluded that the question of whether the Airgas bylaw is permissible is not unambiguously answered by studying the language of the charter provision establishing the staggered board and that this ambiguity should be resolved by reference to a presumption in favor of the shareholder franchise.

Chancellor Chandler's ruling was not a complete surprise to the market. For instance, the widely followed "Deal Professor" column, as well as the "M\&A Law Prof Blog," argued prior to the ruling that such an outcome was warranted on the merits and thus

\footnotetext{
${ }^{15}$ Airgas, Inc. v. Air Products and Chemicals, Inc., Chancery Court opinion, decided October 8, 2010.
} 
could well be expected. ${ }^{16}$ However, the Chancery Court ruling was not fully anticipated by the market either. In fact, at the time of the October 8 hearing, there was a downward movement in Airgas's stock price, which Davidoff attributed to market participants updating upward their estimates of the likelihood of an Airgas victory in light of certain remarks made by the chancellor. ${ }^{17}$

The reaction of Airgas's stock price following the ruling also suggests that the ruling was not fully anticipated by the market. Airgas's stock price rose by $2.7 \%$ at the very beginning of the first trading day (October 11, 2010) after the ruling, an economically significant increase relative the Dow Jones Industrial Average, S\&P500, and NASDAQ Composite Index, which increased by $0.004 \%, 0.015 \%$, and $0.065 \%$, respectively, from the close of market on October $8^{\text {th }}$ to the open of market on October $11^{\text {th }}$.

Therefore, Chancellor Chandler's ruling was a not-fully-anticipated event-giving rise to a treatment outcome (i.e., market reaction) to be studied - in which there were clear sets of affected and unaffected firms. Moreover, firms' treatment status (i.e., whether their shareholder meetings took place early or late in the calendar year) was predetermined by their fiscal year-ends and therefore independent of the rulings.

The ruling was expected - to the extent that it would not be overturned on appeal — to weaken the insulating power of the staggered boards of those companies whose annual meetings ordinarily take place on or after September. Thus, a finding that the ruling was accompanied by positive abnormal returns for such companies (relative to non-impacted companies) would be consistent with the market viewing the antitakeover force of staggered boards as value-decreasing.

\footnotetext{
${ }^{16}$ Davidoff, "Airgas's Novel Question"; Davidoff, "After Losing Vote, What's Next for Airgas?"; Brian J. M. Quinn, "Advantage: Air Products," "M \& A Law Prof Blog" website, October 8, 2010, http: //lawprofessors.typepad.com/mergers/2010/10/advantage-air-products.html.

${ }^{17}$ Davidoff, "The Dwindling Options for Airgas."
} 


\subsection{The November 23 Supreme Court Ruling}

After the initial Chancery Court decision, Airgas appealed to the Supreme Court of Delaware, which held a hearing over the case on November 2. Although the court was expected to announce its decision within days of the hearing, as was commonly the case in its rulings in fast-paced takeover battles, the decision was not announced until three weeks later, on November 23, 2010.18

Instead of focusing on the language of the standard charter provision establishing a staggered board, as did the Chancery Court, the Supreme Court's interpretation of the charter provision relied substantially on "extrinsic evidence," such as the description of the chapter provision by commentators and in company disclosures. The Supreme Court concluded that the standard language of the staggered board provisions should be understood to require that directors serve for three years and thus to preclude Airgastype bylaws that shorten this term significantly by moving up the annual meeting to the beginning of the calendar year. The Supreme Court ruling thus closed the door-opened up by the Chancery Court ruling - for using Airgas-type bylaws to weaken the force of the staggered boards of companies whose annual meeting ordinarily takes place late in the year.

The Supreme Court ruling was not completely unexpected. During the November 8 hearing at the Delaware Supreme Court, the justices directed tough questions to Air Products' counsel, which led some market participants to raise their estimate of the likelihood of the Supreme Court's reversing the lower court ruling. ${ }^{19}$ Furthermore, the Supreme Courts delay in announcing a decision was viewed by market participants as

\footnotetext{
${ }^{18}$ Airgas, Inc. v. Air Products and Chemicals, Inc., Delaware Supreme Court opinion, decided November 23, 2010, C.A. No. 5817.

${ }^{19}$ See, for example, Davidoff, "Staggered Boards and Company Value," New York Times website, November 12, 2010, http://dealbook.nytimes.com/2010/11/12/ staggered-boards-and-company-value, which states that "the questioning of the justices makes me ever so slightly more inclined to see the possibility of a reversal."
} 
increasing the likelihood that it would find the Airgas bylaw invalid; had the Court planned to validate the bylaw and thus pave the way for a shareholder meeting in two months, it would have had strong reason to try to announce its decision quickly to facilitate preparation for the meeting.

As was the case with the Chancery Court ruling, however, the Supreme Court ruling was not fully anticipated by the market. Although Professor Davidoff revised the likelihood of reversal upward in light of the justices' questioning at the hearing, his "Deal Professor" column continued to predict that the Supreme Court would likely affirm the lower court's ruling. ${ }^{20}$ Furthermore, Airgas's stock price fell significantly upon the announcement of the Supreme Court's opinion at 1:30 PM on November $23,{ }^{21}$ by $6.34 \%$ from $\$ 66.20$ at $1: 30 \mathrm{pm}$ to $\$ 62.00$ by market close, consistent with the market not having been certain that Airgas would win. This change in Airgas's stock price, as in the case of the Chancery court decision, is significant relative to the market. From close of market on November 22 to close of market on November 23, Airgas fell by $5.9 \%$ whereas the Dow Jones Industrial Average, S\&P500, and NASDAQ Composite Index fell by 1.7\%, 1.4\%, and $1.5 \%$, respectively.

The not-fully-anticipated nature of the Supreme Court ruling provides us with another event for studying market participants' view on how staggered boards affect firm value. By overturning the lower court ruling that weakened the insulating power of staggered boards of companies whose annual meetings ordinarily take place late in the calendar year, the Supreme Court ruling returned this insulating power to pre-Airgas levels. Thus, a finding that the ruling was accompanied by negative abnormal returns for such companies (compared to non-impacted ones) would be consistent with the market viewing the power

\footnotetext{
${ }^{20}$ Davidoff, "Airgas's Strategic Blink."

${ }^{21}$ It should be noted, however, that the decline in Airgas's stock price was due both to the Supreme Court ruling that the Airgas bylaw is invalid and to the comments in the Supreme Court's opinion that signaled acceptance of the blocking of Air Product's bid by Airgas's directors. These comments could also have reduced the market's estimate of the likelihood that the Delaware courts would require Airgas's directors to pull out the poison pill, a matter being concurrently litigated by Airgas and Air Products.
} 
of staggered boards to delay director replacement by shareholders as value-decreasing.

To mitigate concerns about the possibility that our results may be affected by confounding events, we reviewed all the major news reported by Bloomberg, Dow Jones newswire, and Yahoo! Finance over the two event periods in our study. We were not able to identify a pair of the events that could have produced differential impact on the treatment and control group of firms (firms with late and early annual shareholder meetings, respectively) over the first event window and a differential impact going in the opposite direction over the second event window, nor were we able to identify events that could have produced a differential impact on the treatment and control group of firms in each of the event windows. However, as is the case with other event studies, our review cannot completely rule out the possibility of such events.

\section{Data Description}

We gather data on corporate governance characteristics, particularly the presence of a staggered board, from the SharkRepellent dataset of FactSet Research Systems. The data are available on a cross-section of U.S.-based firms listed on the NYSE, NYSE AMEX, NYSE ARCA, NASDAQ, or NASDAQ Capital Market. ${ }^{22}$

We merge in the data on stock prices and returns. In particular, we obtain October and November 2010 stock prices and returns from Datastream and PERMNO identifiers and historical returns from the Center for Research in Security Prices (CRSP). Finally, we obtain GVKEY identifiers, Global Industry Classification Standard (GICS) industry classification codes, and the most recently available annual financial statement information from Compustat. Throughout the paper we use six-digit GICS codes, which have been shown to better explain stock return co-movements and cross-sectional variation in key financial ratios such as valuation multiples (e.g., Bhojraj, Lee, and Oler, 2003)

\footnotetext{
${ }^{22}$ SharkRepellent data current as of October 12, 2010.
} 
and therefore provide a better classification system to form industry comparison groups. However, using the Fama-French 48 industry definitions does not significantly change our results.

The intersection of the above four datasets provides a sample of 1,956 Delawareincorporated firms. ${ }^{23}$ For our empirical analysis, we follow the governance literature (e.g., Gompers, Ishii, and Metrick, 2003) and exclude all dual-class firms and real estate investment trusts, since they operate under unique corporate governance arrangements. ${ }^{24}$ We also exclude all firms in which insider equity ownership exceeds $50 \%$ and for which the possibility of a control contest is therefore irrelevant, regardless of whether the board is staggered. Keeping these observations in the dataset, however, does not qualitatively change our results. Our final sample consists of 1,649 firms, of which 801 (49\%) have staggered boards.

We also obtain information on annual shareholder meeting dates from ISS Voting Analytics. This dataset provides the dates of annual shareholder meetings for all Russell 3000 firms for the years 2003 to 2011.

\section{Announcement Returns around the Two Court Rul- ings}

\subsection{Announcement Returns and the Court Rulings}

In our natural experiment setup, the firms that are expected to be affected significantly by the Chancery Court ruling (and by the Delaware Supreme Court's subsequent

\footnotetext{
${ }^{23}$ Because the rulings in question set precedents for firms governed by Delaware law, we focus our analysis on Delaware-incorporated firms. While Delaware rulings may have some influence on the rulings of judges in other states considering similar cases involving non-Delaware firms, they are not binding on those judges.

${ }^{24}$ Real estate investment trusts are defined as any firms with a four-digit Standard Industrial Classification code of 6798 .
} 
reversal) - our treatment group - are firms that, like Airgas, have a staggered board and hold their annual meetings later in the calendar year. We classify a firm as belonging to the treatment group if it has a staggered board and its most recent annual meeting took place in September (like Airgas) or later in the calendar year.

In contrast, firms that are clearly unaffected by the two Delaware court rulings - our control group - are those that have a staggered board and have their annual meetings in the earlier part of the calendar year. We classify a firm as belonging to the control group if it has a staggered board and its last annual meeting took place in March or earlier in the calendar year. Our sample includes 139 firms (77 of which are treated). ${ }^{25}$

Our analysis focuses on the comparison of firms that have staggered boards because, as documented in earlier literature, these firms may be substantially different from those without staggered boards along several dimensions. Including non-staggered-board firms as controls may therefore obfuscate inferences from observed differences in announcement returns. Instead, throughout our analysis, we use the sample of non-staggered-board firms as a placebo test, by comparing the differences in announcement returns between lateand early-meeting firms among this group.

We begin by studying the stock market returns experienced by affected firms during the two-day window following the announcements of the Chancery Court and the Supreme Court rulings. The Chancery Court ruling took place after the close of the stock market on Friday, October 8, 2010; the first trading day following the ruling was thus Monday, October 11, which was Columbus Day. Because trading volumes on Columbus Day are lower than usual ${ }^{26}$ and because most of the substantive, in-depth media discussion of the

\footnotetext{
${ }^{25}$ In unreported tests, we vary the treatment and control group definitions by relaxing the definition of later and earlier. We consider the following variants of the treatment group definition-having annual meetings on or after July, June, and May - and match each to the following control group-having annual meetings on or prior to April, April, and May, respectively. Generally speaking, as we relax the definitions of "earlier" and "later" our estimated treatment effects achieve greater statistical significance but with marginally lower magnitudes.

${ }^{26}$ In the case of Columbus Day 2010, for example, the total dollar trading volume was $80 \%$ and $81.6 \%$ of the previous and next trading days' total dollar trading volumes, respectively, and $79.3 \%$ and $75.8 \%$
} 
Chancery Court ruling came out only on Monday, October 11 and Tuesday, October 12, ${ }^{27}$ we examine the two-trading-day window ending at the close of the market on October 12. Unlike the Chancery Court ruling, the Supreme Court's opinion was released during market trading hours at 1:30 PM on November 23. Given the short two-and-a half-hour window on the first trading day, we again examine the two-trading-day window from the close of November 22 to the close of November 24 .

We focus on risk-adjusted excess returns as dependent variables to account for the possibility that differences in raw returns $\left(r_{t}\right)$ between groups of firms may reflect differences in risk characteristics. Following standard procedures, risk-adjusted excess returns are computed in two steps, as follows. First, each firm's loadings on the Fama and French (1993) three factors and the Fama and French (1996) "up minus down" momentum factor $(U M D)$ are estimated using the most recently available 120 trading days' data ending on or prior to September 30, 2010. That is, for each firm we obtain $\left(\hat{\beta}_{i, M}, \hat{\beta}_{i, S M B}, \hat{\beta}_{i, H M L}\right.$, $\left.\hat{\beta}_{i, U M D}\right)$ from the following time-series regression.

$$
r_{t}=\alpha_{1}+\beta_{M} \times M k t R f_{t}+\beta_{S M B} \times S M B_{t}+\beta_{H M L} \times H M L_{t}+\beta_{U M D} \times U M D_{t}+\varepsilon_{t}
$$

We then obtain excess announcement window returns by taking the residuals from a of the two succeeding Mondays' total dollar trading volumes.

${ }^{27}$ See Elizabeth Amon, "Foreclosure Suits, BP, Airgas, UBS in Court News," Bloomberg website, October 11, 2010, http://www.bloomberg.com/news/2010-10-11/ fdic-suits-swatch-ubs-airgas-park-avenue-bank-in-court-news.html; $\quad$ Eduardo Gallardo, "Important Chancery Court Opinion for Corporations with Staggered Boards," Harvard Law School Forum on Corporate Governance and Financial Regulation website, October 11, 2010, http://blogs.law.harvard.edu/corpgov/2010/10/12/ important-chancery-court-opinion-for-corporations-with-staggered-boards; Gennine Kelly, "Update: Airgas to Fight Court Ruling over Annual Meeting," CNBC website, October 11, 2010, http: //www.cnbc.com/id/39613741/Update_Airgas_to_Fight_Court_Ruling_Over_Annual_Meeting; Dawn McCarty and Jack Kaskey, "Airgas to Appeal Delaware Ruling on Meeting Date in Air Products Dispute," Bloomberg website, October 11, 2010, http://www.bloomberg.com/news/2010-10-11/ airgas-to-appeal-delaware-ruling-on-meeting-date-in-air-products-dispute.html;

Brian J. M. Quinn, "Airgas to Appeal," "M\&A Law Prof Blog" website, October 11, 2010, http://lawprofessors.typepad.com/mergers/2010/10/page/2; Davidoff, "The Dwindling Options for Airgas." 
cross-sectional regression of raw announcement window returns $\left(\right.$ AnnRet $\left._{t}\right)$ on the estimated factor sensitivities. That is, for each firm, we obtain the fitted residual $\hat{\delta}_{i, t}$ from the following cross-sectional regression.

$$
\text { AnnRet }_{i, t}=\alpha_{2}+\lambda_{M} \times \hat{\beta}_{i, M}+\lambda_{S M B} \times \hat{\beta}_{i, S M B}+\lambda_{H M L} \times \hat{\beta}_{i, H M L}+\lambda_{U M D} \times \hat{\beta}_{i, U M D}+\delta_{i, t}
$$

We integrate the two events in our announcement returns analysis by pooling the observations from both events. Following Larcker, Ormazabal, and Taylor (2011), we multiply the excess returns from the second ruling by negative one, since we expect these offsetting events' consequences to be of opposite signs. The pooling of the two events has the advantage of increasing the sample size and the power of our empirical tests.

Table I shows the results of our testing for differences in announcement window returns between treated and control firms. We do so by regressing the adjusted two-day excess returns on the treatment group indicator. As a control, we include an indicator for the second ruling date, Event 2, to account for possible differences in the mean returns between the two event dates.

Our initial regression estimation of the average treatment effect for the affected firms partially relies on the fact that a firm's treatment status was historically predetermined, and is therefore unlikely to be related to the court rulings or their expected outcomes. Based on ISS Voting Analytics data, Figure 1 displays the relations between fiscal yearend dates and annual meeting dates for Russell 3000 firms over the years 2003 to 2011.

Figure 1 displays the distribution of the fiscal year-end months and the months of annual shareholder meetings. The majority of Russell 3000 firms have fiscal years that run in accordance with the calendar year and hold annual shareholder meetings four to six months after fiscal year-end, between April and June. Figure 2 shows that, about $94 \%$ of the time, the annual shareholder meeting takes place between four and six months after a firm's fiscal year-end and $98 \%$ of the time the meeting takes place between three 
and seven months after the fiscal year-end. Moreover, both fiscal year-ends and months of shareholder meetings are very stable over time. For $99.7 \%$ of firms, the fiscal yearend remained the same year after year, while about $96 \%$ of firms held successive annual shareholder meetings 11 to 13 months apart.

Therefore, whether a firm was affected or unaffected by the two Delaware court rulings was historically predetermined, largely based on the company's historic choice of a fiscal year-end. At the time of going public, some firms chose a fiscal year different from the calendar year for industry (e.g., seasonality or operating cycle) or cost-saving reasons (e.g., accounting firms are willing to charge less if a firm's financial statements can be prepared at times other than the high-pressure periods when most firms' statements are due). Importantly, prior to the Airgas battle and the introduction of the novel technique of the Airgas bylaw, the choice of the fiscal year and the annual meeting timing was not viewed as relevant for corporate control purposes. Thus, this choice can be viewed as unlikely to be related to the two Delaware court rulings, their expected outcomes, as well as the expected effects of staggered boards (and their weakening) on shareholder value. The implicit assumption in our natural experiment is that the choice of early vs. late annual meetings (or, having fiscal years ending around April to June or around September, respectively) is essentially random. We think the assumption is reasonable particularly within industry; ${ }^{28}$ however, we conduct a variety of robustness tests - including placebo tests, propensity score matching, and simulations - to help rule out alternative explanations.

In Table I, columns (1) and (2) show evidence that validating the Airgas bylaw and weakening the antitakeover force of staggered boards provide significantly positive returns

\footnotetext{
${ }^{28}$ That there are systematic differences between firms with December and non-December year-end firms is well documented (e.g., Huberman and Kandel, 1989; Smith and Pourciau, 1988). Most notably, smaller firms are more likely to choose fiscal years ending in a non-December month, such as March, June, or September. However, the systematic factors driving the choice between non-December fiscal year end months, particularly across firms within the same industry, seem to be less clear.
} 
for treated firms compared to control firms. Over the two-day event window, we find that treated firms, on average, outperformed control firms by 0.7595 percentage points when industry controls are not used [column (1)] and by 0.9612 percentage points when GICS6 industry fixed effects are included $\left[\right.$ column (2)]. ${ }^{29}$ Both coefficients are significant at the $10 \%$ level. This relatively low level of significance might be due to the limited number of observations resulting from our focus on firms that are incorporated in Delaware and have annual meetings either early or late in the year. Thus, while our results are consistent with market participants viewing staggered boards as bringing about lower firm value, any future reliance on our results should keep in mind the low level of significance in this and some subsequent tests.

Assuming that our rejection of the null is valid, we note that the magnitude of the estimated differences in mean announcement returns between the treated and nontreated firms may potentially be attenuated by two factors: first, the extent to which the Chancery and Supreme Court rulings were, prior to the decision, viewed by the market as possible; and second, the extent to which the market expected the Chancery Court ruling to be reversed by the Delaware Supreme Court. Thus, insofar as the identified positive returns for the treated firms are significantly different from zero, they are likely to understate the market's estimate of the value for the treated firms of permitting Airgas-type bylaws.

Furthermore, as we noted earlier, permitting Airgas-type bylaws would have merely weakened rather than eliminated the antitakeover force of staggered boards, enabling shareholders to decrease - but not eliminate - the extent to which staggered boards can delay the replacement of a majority of directors sought by a shareholder majority. In

\footnotetext{
${ }^{29} \mathrm{We}$ include the industry fixed effects specification to account for the possibility that the treatment status and market reactions could be confounded by underlying differences in industry characteristics. Thus, whereas the baseline model implicitly assumes that the choice of early vs. late meeting is random across firms, the fixed-effects model implicitly assumes that this choice is random across firms within the same industry.
} 
addition, it may be possible, although we believe it is unlikely, that the market expected validation of Airgas-type bylaws to be followed by firms' moving their annual meetings to early in the calendar year to preempt the use of such bylaws. Thus, whereas our results may understate the market's estimate of the value for treated firms of permitting Airgas-type bylaws, this estimate in turn may likely be lower than the market's estimate of the effect of staggered boards on firm value.

\subsection{Alternative Interpretation and Propensity Score Matching}

An alternative interpretation of our results is that our finding of differences in announcement returns may not be informative of the market's views of the causal relation between staggered boards and shareholder value but, rather, reflects the market's views with respect to some firm characteristics that differ between the treated and control groups and are related to the Delaware courts' decisions. To test for the possibility that alternative causal mechanisms may be driving our finding, we perform a placebo test based on our sample of Delaware firms without staggered boards. If the market reactions we document in columns (1) and (2) of Table I reflect the market's views on the effect of weakening staggered boards on shareholder value, then we do not expect to find any differences in announcement window returns between late- and early-meeting non-staggered-board firms..

Indeed, columns (3) and (4) of Table I show that, among non-staggered-board firms, there were no statistically significant differences in the announcement returns between late- and early-meeting firms. Moreover, the differences in the announcement returns are attenuated toward zero compared to the estimates of columns (1) and (2). Over the two-day event window, we find that late-meeting non-staggered-board firms have excess returns that are 0.0291 and 0.1407 percentage points larger than early-meeting non-staggered board firms in the specifications without and with industry fixed effects, 
respectively; these differences in excess returns are not statistically different from zero at the $10 \%$ level.

We delve further into the possibility that the market responses to the Delaware court rulings could reflect some alternative causal mechanism. In particular, it might be conjectured that the Chancery Court ruling was viewed by the market as significant not only because of its particular conclusion but also as a signal of greater openness toward takeovers. To the extent that control contests are more relevant to our treatment group of late-meeting firms, our findings in columns (1) and (2) of Table I may simply reflect the market's views on the positive effect of greater takeover likelihood on shareholder value.

To explore this alternative, we analyze the differences in excess announcement returns by employing a propensity-score-matched sample methodology to compare treated and control firms that have similar firm characteristics relevant to control contests. Drawing on the study of Cremers, Nair, and John (2009), we estimate propensity scores based on the following firm characteristics relevant to takeovers: Tobin's $\mathrm{Q}(Q)$, the ratio of cash to total assets (Cash), the log of market capitalization (Size), industry takeover intensity (Industry), the ratio of long-term debt to assets (Leverage), return on assets $(R O A)$, and the percentage of shareholdings held by the top 10 owners (Top 10 Owners), property, plant and equipment to total assets ratio $(P P \& E) .{ }^{30}$

Table II reports a logistic estimation of the likelihood of being treated, which is modeled to be a function of the above firm characteristics. Column (1) reports the coefficients while column (2) reports the marginal effects evaluated at the sample means.

\footnotetext{
${ }^{30} Q$ is computed, following Kaplan and Zingales (1997), as the market value of assets divided by the book value of assets where the market value of assets equals the book value of assets plus market value of common stock less the sum of the book value of common stock and balance sheet deferred taxes. Size is taken from the most recently available annual financial statements in Compustat. Industry is defined as the percentage of firms in the four-digit GICS industry that were taken over in calendar year 2009. $R O A$ is defined as operating income divided by the book value of assets from the end of the previous fiscal year.
} 
Indeed, we find some evidence that our treatment group of late-meeting firms is associated with some dimensions of takeover likelihood. For example, we find that, all else equal, smaller firms and firms from industries with higher takeover intensity are more likely to be in our treatment group. On the other hand, we also find that firms with higher ROA are more likely to have late shareholder meetings, which is inconsistent with a higher takeover likelihood.

Similarly, Panel A of Table III shows that the firms in the treatment group, on average, are smaller and come from industries with greater takeover intensity, with differences in means that are statistically significant at the $1 \%$ level. Our evidence therefore lends some support to the hypothesis that control contests may be more relevant for treatment firms, raising the possibility that market reactions around the Delaware announcement dates reflect reactions to perceived changes in the Delaware courts' attitude toward takeovers in general rather than reactions to changes in the antitakeover force of staggered boards

To address this possibility, we employ propensity score matching methods, which have become standard and commonly employed methodologies for making causal inferences using observational data that are not produced by controlled experimental settings (e.g., Rosenbaum and Rubin, 1983). Using the predicted values arising from the logistic model of Table II, we create two types of matched sample: first, we match each treated firm with the closest control firms in the common support by propensity scores; second, we match each treated firm with the closest control firms in the common support within the same industry by propensity scores, where control firms are drawn with replacement. A choice in constructing matched samples is the number of controls with which to match each treated firm. Choosing a greater or lesser number of matches is a trade-off between greater efficiency and greater bias (or the quality of the match), respectively. Given our limited sample, we consider matching each treated firm with one or two control firms $(m=1, m=2$, respectively). 
Panels B and C of Table III report, for each matched sample, the differences between the treated and control groups in average propensity scores and in firm characteristics that make control contests more relevant. Overall, our matched samples produce good balance in all covariates and, in all cases, the average propensity scores are statistically no different between the treated and control firms. In Panel B, we find that the $m=1$ matched sample produces good balance along all covariates, whereas the $m=2$ matched sample results in a control group with a statistically lower (at the 5\% level) average return on assets. Panel $\mathrm{C}$ reports the means comparison for the within-industry matched sample, created by matching, for each treatment firm, control firms within the same fourdigit GICS (GICS4) industry. ${ }^{31}$ We find that the $m=1$ within-industry matched sample produces good balance, with the exception of average leverage, which is statistically higher in the control sample (at the $5 \%$ level). The $m=2$ within-industry matched sample produces good balance along all covariates.

Panel A of Table IV reports the estimated treatment effects for each of the four matched samples. Using the $m=1$ matched sample, we find that treatment firms experienced excess returns 1.1496 percentage points higher than those for the matched control firms, with statistical significance at the $11 \%$ level. The $m=1$ within-industry matched sample produced stronger statistical results, with treatment firms experiencing excess returns 1.0900 percentage points higher than those for the matched control firms, an effect that is statistically significant at the $5 \%$ level. Using the $m=2$ matched sample, we find that treatment firms experienced excess announcement window returns 0.9648 percentage points higher than those for the matched control firms, though we do not find this effect to be significant at conventional levels. ${ }^{32}$ Similar to before, the $m=2$ within-

\footnotetext{
${ }^{31}$ We choose the coarser GICS4 industry classification to achieve greater balance in the distribution of treated and control firms across industry classifications.

${ }^{32}$ Note that the number of observations reports the total number of firms (treated and control) across two events. Observations are equal for the $m=1$ and $m=2$ matched samples since in the $m=2$ case the two closest observations to each treated firm are averaged to be a composite match.
} 
industry matched sample produced stronger results, with treatment firms experiencing excess returns of 0.9954 percentage points higher than those for the matched control firms, an effect that is statistically significant at the $10 \%$ level.

As a robustness test, we also conduct the propensity-score-matched sample exercise on the sample of placebo firms - i.e., non-staggered-board firms with late or early annual shareholder meetings. To the extent that our estimation of propensity scores does not capture some natural differences between late- and early-meeting firms, such a placebo test should reflect the expected direction of the bias. In all cases, we find no significant differences (at the 10\% level) in excess announcement window returns between late- and early-meeting firms, suggesting that it is unlikely that natural differences between the two groups of firms are driving the results of Panel A. Together, our evidence in Panels A and B of Table IV is consistent with markets viewing staggered boards as inducing lower shareholder value.

\subsection{Simulation Exercise}

We use a simulation approach to assess the significance of our results, taking advantage of the fact that our setting contains two opposing events - the Chancery Court ruling that produced positive relative returns for treated firms and the Supreme Court ruling that produced negative relative returns for treated firms. In particular, we ask the question: how likely is it to observe treatment effects as large as the ones in our two events and going in the opposite directions on two random days? To answer such a question, we first re-estimate the treatment effects, but for each event separately. Then we compare the pairs of treatment effects to a reference distribution which we bootstrap from the non-event dates of January 2 to June 30, 2010.

For each two-day window in this non-event period, we replicate the specifications in Panel A of Tables I and IV and generate bivariate benchmark distributions of coefficients 
over all pairs of trading days. We then consider whether the observed differences in announcement window returns between the treated and control groups across the two event dates appear abnormal when compared to the simulated benchmark distribution.

To begin the exercise, we compute excess returns for each two-day window in a twostep procedure similar to that used in Tables I and IV (see Section 4.1). Using the excess returns, we first estimate for each two-day window in the non-event window the regression models of Table I, regressing excess two-day returns on the treatment group indicator, with and without industry fixed effects. Unlike Table I, our simulation considers only one event window at a time rather than pooling across two event dates; therefore, an indicator for the second event date is not included. Based on the simulated coefficients, we construct a benchmark bivariate distribution of estimated coefficients on the treatment group indicator over all unique pairs of dates over the event window.

Rows (1) and (2) of Table $\mathrm{V}$ report the comparisons of our observed ordinary least squares (OLS) coefficients over the two Delaware ruling dates to the simulated benchmark distributions. Our basic OLS estimates without (with) industry fixed effects find that the treated group of firms outperforms the control group by 0.6039 (0.8282) percentage points on the first event date but underperforms the control group by 0.9151 (1.0941) percentage points on the second event date. Figure 3 visually compares our observed OLS estimates to nonparametric Gaussian kernel density estimates of our simulated bivariate distributions, which are approximately bivariate normal, centered around zero.

Relative to the simulated benchmark distributions, we find that this pattern of large, positive relative returns for treated firms from the Chancery Court ruling and large, negative relative returns for treated firms from the Supreme Court ruling are unlikely to be the result of random sampling. In only 0.0093 (0.0028) of our simulated trials using the no-fixed-effects (fixed-effects) model do we observe a first-event coefficient at least as large as the observed OLS coefficient of 60.39 (82.82) and a second-event coefficient at 
least as small as the observed coefficient of $-91.51(-109.41)$.

We also perform the same simulation using the propensity-score-matched sample estimation procedure of Tables II to IV. For each two-day window in the non-event period, we estimate the average treatment effect on the treated by matching each treated firm to the following four types of control firms: (1) the $m=1$ closest control firm by propensity score, (2) the $m=1$ closest control firm within the same GICS4 industry by propensity score, (3) the $m=2$ closest control firms by propensity score, and (4) the $m=2$ closest control firms within the same GICS4 industry by propensity score. For the purposes of the simulation, propensity scores are estimated at the beginning of the non-event window, using data available as of January 1, 2010.

Rows (3) to (6) of Table V report the comparisons of our observed propensity-scorematched sample estimates over the two Delaware ruling dates to the simulated benchmark distributions. Our propensity score estimates using $m=1$ matched control (within the same GICS4 industry) find that the treated group of firms outperforms the control group by 1.0977 (1.2550) percentage points on the first event date, but underperforms the control group by 0.3914 (0.9250) percentage points on the second event date. Similarly, our propensity score estimates using $m=2$ matched controls (within the same GICS4 industry) find that the treated group outperforms the control group by 1.2204 (1.0224) percentage points on the first event date but underperforms the control group by 0.7092 (0.9685) percentage points on the second event date. Figures 4 and 5 visually compare our observed propensity score estimates to nonparametric Gaussian kernel density estimates of our simulated bivariate distributions, which are again approximately bivariate normal, centered around zero.

Consistent with the OLS simulations above, we find that the patterns in our propensity score estimates of large, positive relative returns for treated firms from the Chancery Court ruling and large, negative relative returns for treated firms from the Supreme 
Court ruling are unlikely to be the result of random sampling. In only 0.0079 (0.0181) of our simulated trials using the $m=1$ matched sample (within the same GICS4 industry) do we observe a first-event estimate at least as large as the observed propensity score estimate of 190.77 (125.50) and a second-event estimate at least as small as the observed propensity score estimate of -39.14 (-92.50). Similarly, in only 0.0043 (0.00276) of our simulated trials using the $m=2$ matched sample (within the same GICS4 industry) do we observe a first-event estimate at least as large as the observed propensity score estimate of 122.04 (102.24) and a second-event estimate at least as small as the observed propensity score estimate of $-70.92(-96.85)$.

In summary, our simulation results indicate that our observed market reactions - of positive relative returns for treated firms from the Chancery Court ruling and negative relative returns for treated firms from the Supreme Court ruling - are highly unlikely to have arisen from random sampling variation. Together with our OLS and propensity score estimation results, our evidence is consistent with the hypothesis that the market views the power of staggered boards to delay director replacement by shareholders as value-decreasing.

\section{Conclusion}

This paper seeks to make an empirical contribution to the study of the sources of the well-documented correlation between governance provisions insulating directors from removal-particularly the use of staggered boards - and lower firm value. Our identification comes from a natural experiment consisting of a recent Delaware Chancery Court ruling enabling shareholders to weaken the extent to which staggered boards insulate directors from removal and the ruling's subsequent reversal by the Delaware Supreme Court. This natural experiment enables us to identify how market participants, in the 
aggregate, view the average effect of staggered boards on firm value for those affected firms.

In particular, we use three ways to compare the returns of the firms most affected by the rulings (the treated) with the returns of the firms that are unaffected by the rulings (the control). We find evidence consistent with market participants viewing staggered boards as value-reducing on average for the affected firms. These findings contribute causal evidence to the ongoing policy debate on the desirability of staggered boards. 


\section{References}

AbAdie, A., And G. ImBens (2006): "Large sample properties of matching estimators for average treatment effects," Econometrica, 74, 235-267.

Bates, T., D. Becher, and M. Lemmon (2008): "Board classification and managerial entrenchment: Evidence from the market for corporate control," Journal of Financial Economics, 87(3), 656-677.

Bebchuk, L., J. Coates, and G. Subramanian (2002): "The powerful antitakeover force of staggered boards: Theory, evidence, and policy," Stanford Law Review, 54, 887-951.

Bebchuk, L., And A. Cohen (2005): "The costs of entrenched boards," Journal of Financial Economics, 78(2), 409-433.

Bebchuk, L., A. Cohen, and A. Ferrell (2009): "What matters in corporate governance?," Review of Financial Studies, 22(2), 783-827.

Bebchuk, L., A. Cohen, and C. C. Wang (2011): "Staggered boards and the wealth of shareholders: evidence from two natural experiments," Discussion Paper No. 697, John M. Olin Center for Law, Economics, and Business, Harvard Law School.

Becker, B., D. Bergstresser, and G. Subramanian (2012): "Does shareholder proxy access improve firm value? Evidence from the business roundtable challenge," Discussion paper, National Bureau of Economic Research.

Bhagat, S., And R. Jefferis (1991): "Voting power in the proxy process: The case of antitakeover charter amendments," Journal of Financial Economics, 30(1), 193-225.

Bhagat, S., And R. Romano (2002): "Event studies and the law: Part II: Empirical studies of corporate law," American Law and Economics Review, 4(2), 380-423.

Bhojraj, S., C. Lee, And D. Oler (2003): "What's my line? A comparison of industry classification schemes for capital market research," Journal of Accounting Research, 41(5), 745-774.

Binder, J. (1985): "Measuring the effects of regulation with stock price data," The RAND Journal of Economics, 16, 167-183.

ChHaochharia, V., And Y. Grinstein (2007): "Corporate governance and firm value: The impact of the 2002 governance rules," The Journal of Finance, 62(4), 1789-1825.

Contes, J. (2000): "Takeover defenses in the shadow of the pill: A critique of the scientific evidence," Texas Law Review, 79, 271-382.

Cremers, K., V. Nair, And K. John (2009): "Takeovers and the cross-section of returns," Review of Financial Studies, 22, 1409-1445. 
EASTerbrook, F., AND D. Fischel (1981): "The proper role of a target's board in responding to a tender offer," Harvard Law Review, 94, 1161-1204.

FALEye, O. (2007): "Classified boards, firm value, and managerial entrenchment," Journal of Financial Economics, 83(2), 501-529.

FAma, E., And K. French (1993): "Common risk factors in the returns on stocks and bonds," Journal of Financial Economics, 33(1), 3-56.

(1996): "Multifactor explanations of asset pricing anomalies," The Journal of Finance, 51, 55-84.

Gompers, P., J. Ishin, And A. Metrick (2003): "Corporate governance and equity prices," The Quarterly Journal of Economics, 118(1), 107-155.

Grossman, S., and O. Hart (1980): "Takeover bids, the free-rider problem, and the theory of the corporation," The Bell Journal of Economics, 11, 42-64.

Guo, R., T. Kruse, and T. Nohel (2008): "Undoing the powerful anti-takeover force of staggered boards," Journal of Corporate Finance, 14(3), 274-288.

Hochberg, Y., P. Sapienza, and A. Vissing-Jørgensen (2009): "A lobbying approach to evaluating the Sarbanes-Oxley Act of 2002," Journal of Accounting Research, $47(2), 519-583$.

Huberman, G., and S. Kandel (1989): "Firms' fiscal years, size and industry," Economics Letters, 29(1), 69-75.

Kaplan, S., And L. Zingales (1997): "Do investment-cash flow sensitivities provide useful measures of financing constraints?," The Quarterly Journal of Economics, 112(1), 169-215.

Karpoff, J., and P. Malatesta (1989): "The wealth effects of second-generation state takeover legislation," Journal of Financial Economics, 25(2), 291-322.

Larcker, D., G. Ormazabal, and D. Taylor (2011): "The market reaction to corporate governance regulation," Journal of Financial Economics, 101, 431-448.

MacKinlay, A. (1997): "Event studies in economics and finance," Journal of Economic Literature, 35(1), 13-39.

Manne, A. C. (1965): "Mergers and the Market for the Corporate Control," Journal of Political Economy, 75, 110-118.

Masulis, R., C. WANG, And F. XIE (2007): "Corporate governance and acquirer returns," The Journal of Finance, 62(4), 1851-1889. 
Rosenbaum, P., and D. Rubin (1983): "The central role of the propensity score in observational studies for causal effects," Biometrika, 70, 41-55.

SCHWERT, G. (1981): "Using financial data to measure effects of regulation," Journal of Law and Economics, 24(1), 121-158.

Smith, D. B., And S. Pourciau (1988): "A comparison of the financial characteristics of December and non-December year-end companies," Journal of Accounting and Economics, 10(4), 335-344.

Stein, J. (1988): "Takeover threats and managerial myopia," The Journal of Political Economy, 96, 61-80.

Stulz, R. (1988): "Managerial control of voting rights: Financing policies and the market for corporate control," Journal of Financial Economics, 20, 25-54. 


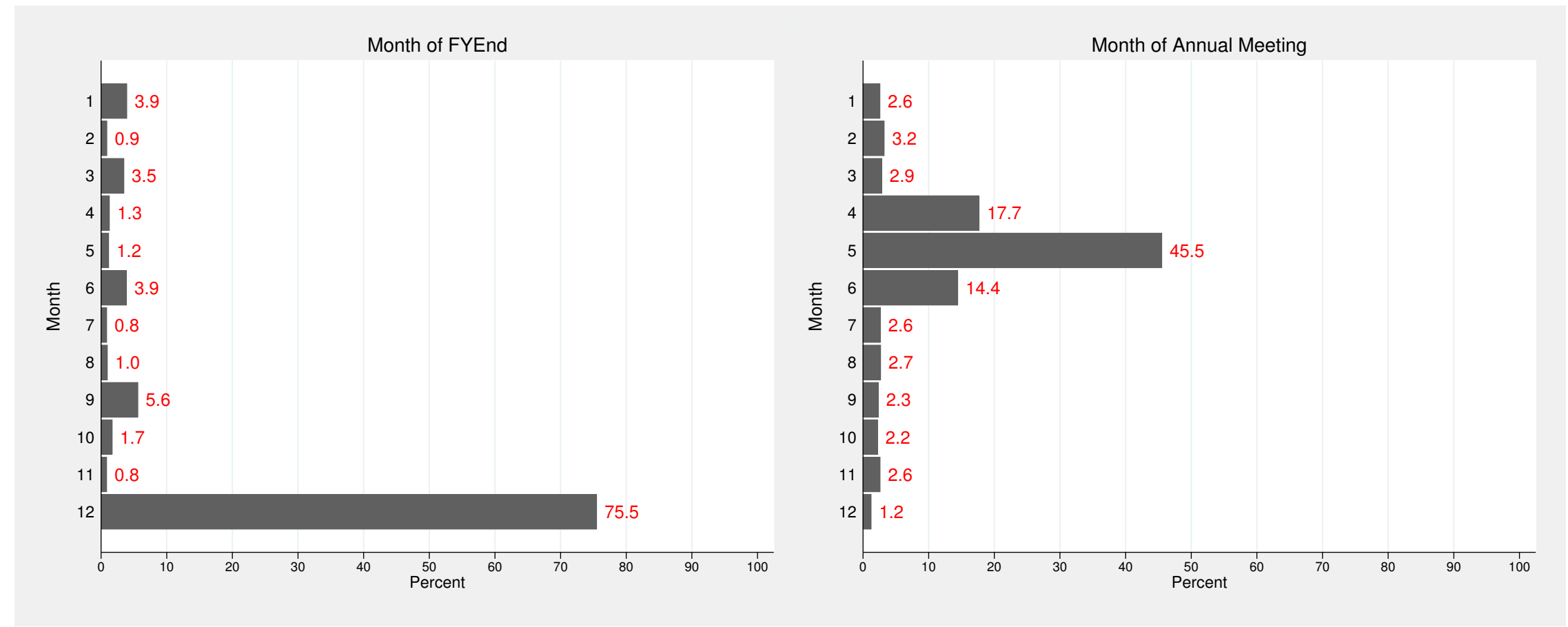

Figure 1. Month of Fiscal Year-end and Annual Shareholder Meeting

Figure 1 displays the distributions of, from left to right, the fiscal year-end months and the months of annual meetings. Our data are from the intersection of Voting Analytics and Compustat, from 2003 to 2011. 


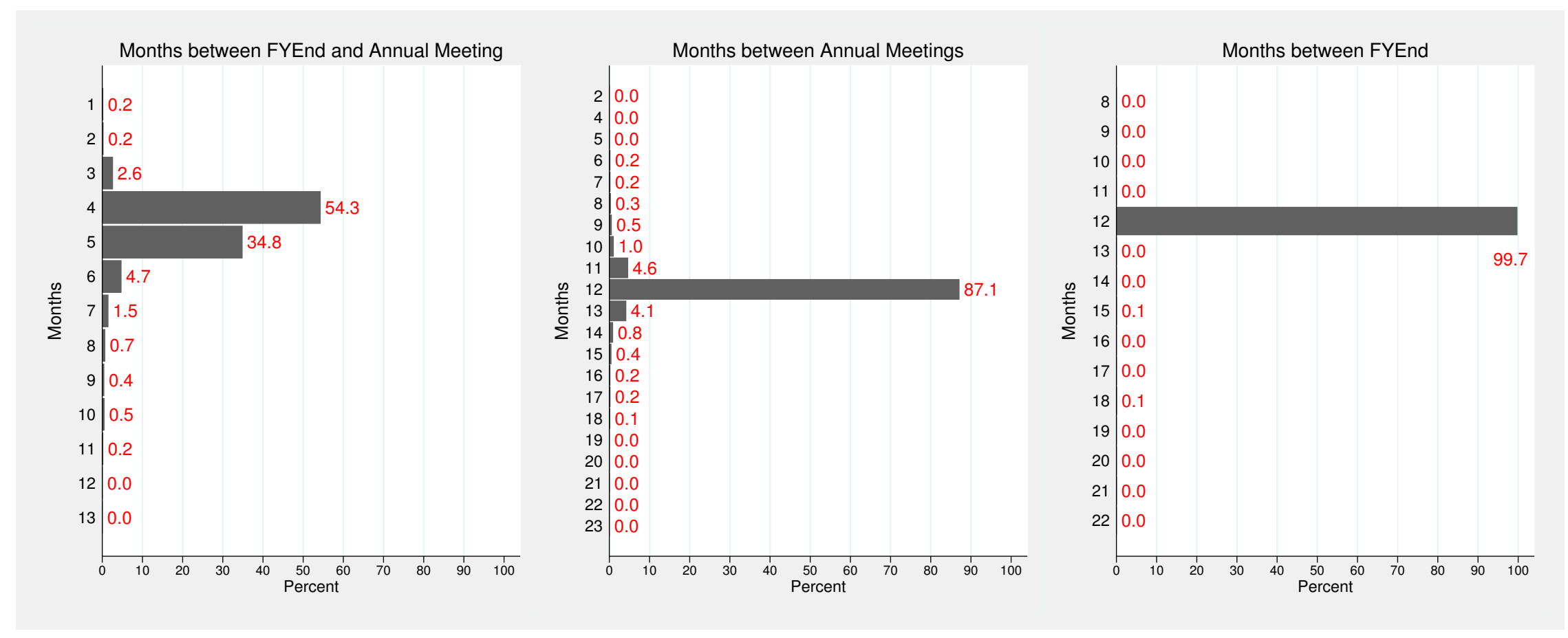

Figure 2. Months between Fiscal Year-end and Annual Shareholder Meeting

Figure 2 displays the distributions of, from left to right, the number of months between the fiscal year-end and the next shareholder meeting, the number of months between consecutive annual shareholder meetings, and the number of months between consecutive fiscal year-ends. Our data are from the intersection of Voting Analytics and Compustat, from 2003 to 2011. 


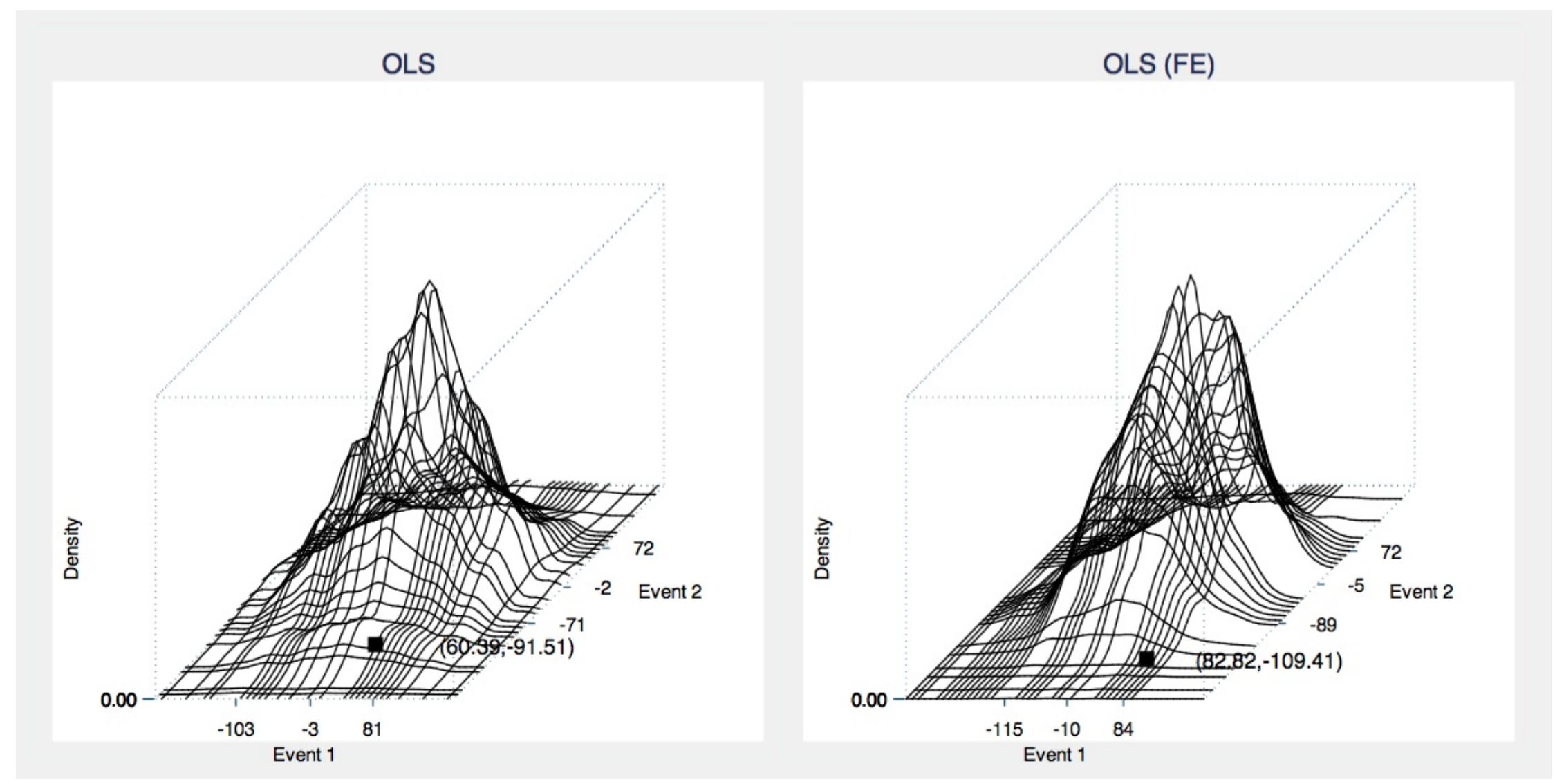

Figure 3. Simulated Bivariate Distribution of Treatment Effects: OLS Estimates

This figure displays the nonparametric Gaussian kernel bivariate density estimates of the simulated OLS treatment effect estimates over all unique pairs of non-event trading dates from January 2 to June 30, 2010, where non-event estimates are obtained as follows: for each trading day, the two-day risk-adjusted returns are regressed on a treatment indicator, with and without fixed effects. The left-hand (right-hand) side of the figure reports simulated coefficients without (with) GICS6 industry fixed effects. 


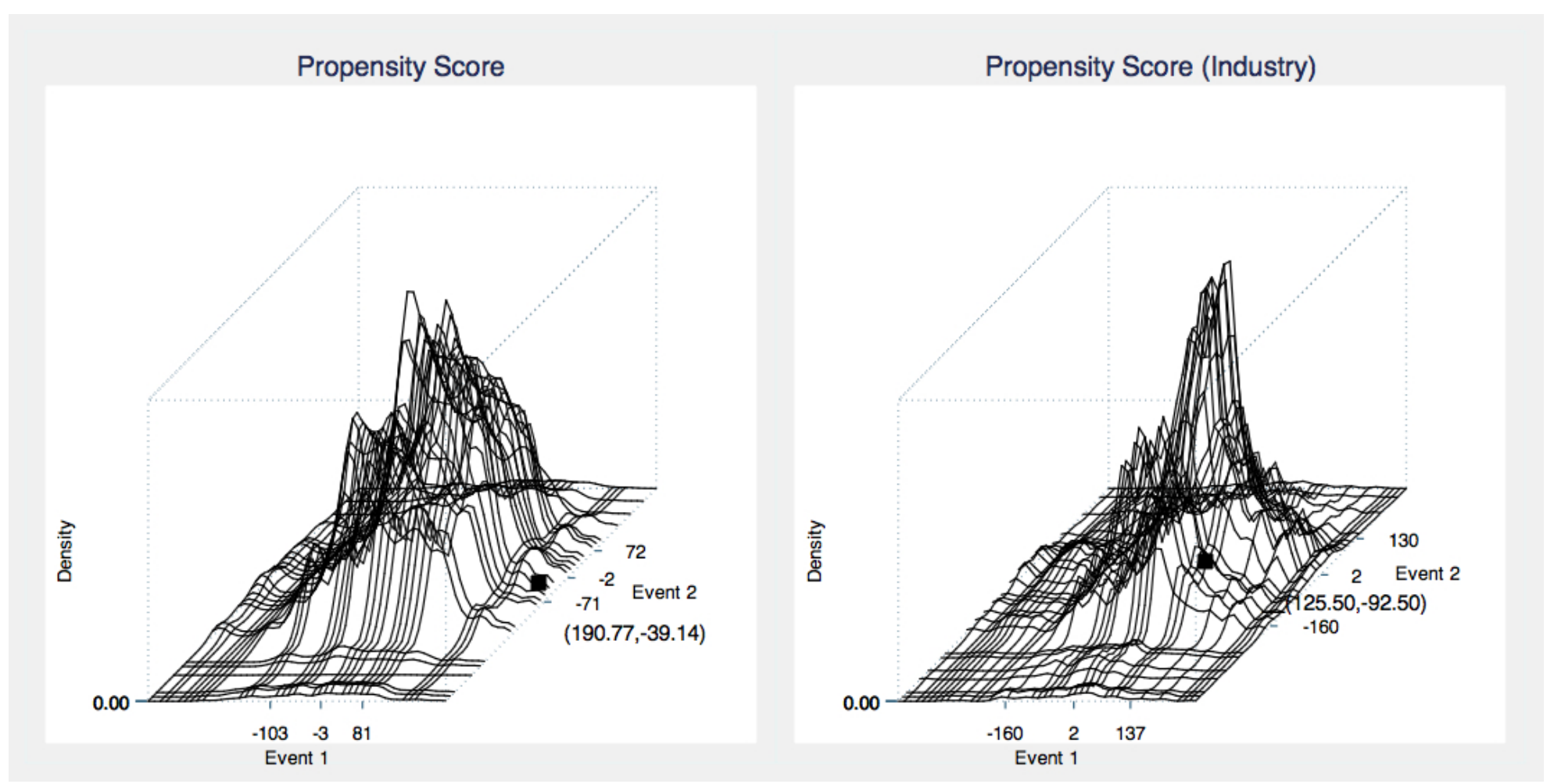

Figure 4. Simulated Bivariate Distribution of Treatment Effects: Propensity Score Estimates $(m=1)$

This figure displays the nonparametric Gaussian kernel bivariate density estimates of the simulated propensity score estimates of the average treatment effect for the treated, simulated over all unique pairs of non-event trading dates from January 2 to June 30 , 2010, where non-event estimates are obtained as follows: for each trading day, the propensity score estimates are computed for the treatment effect for the treated by matching for each treated firm the $m=1$ closest propensity-matched controls. The right-hand side figure reports simulated propensity score estimates that match controls within the same GICS4 industry grouping. 


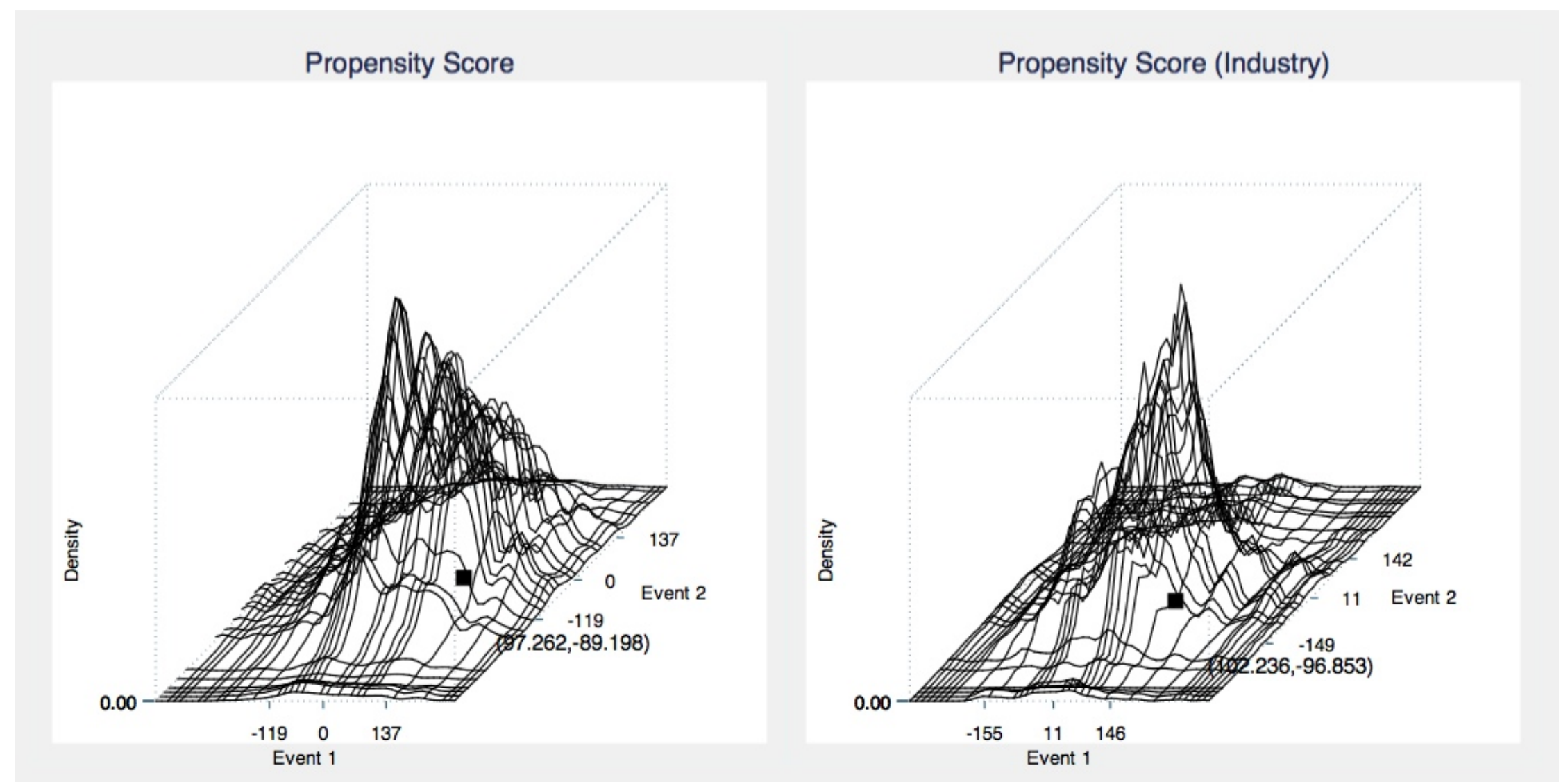

Figure 5. Simulated Bivariate Distribution of Treatment Effects: Propensity Score Estimates $(m=2)$

This figure displays the nonparametric Gaussian kernel bivariate density estimates of the simulated propensity score estimates of the average treatment effect for the treated, simulated over all unique pairs of non-event trading dates from January 2 to June 30 , 2010, where non-event estimates are obtained as follows: for each trading day, the propensity score estimates are computed for the treatment effect for the treated by matching for each treated firm the $m=2$ closest propensity-matched controls. The right-hand side figure reports simulated propensity score estimates that match controls within the same GICS4 industry grouping. 


\section{Table I. Announcement Returns around the Two Delaware Court Rulings}

Table I reports the results from pooled ordinary least squares (OLS) regressions, pooling the October 8, 2010 and November 23, 2010 ruling returns, of two-day risk-adjusted ruling announcement returns on a treated indicator variable and an indicator variable for the second event date (Event 2). We pool the two events and multiply risk-adjusted returns on the second event date by -1 . Risk-adjusted returns are computed in two steps, as follows. First, each firm's loadings on the Fama and French (1993) three factors and the Fama and French (1996) UMD momentum factor are estimated using the most recently available 120 trading days' data ending on or prior to June 30, 2010. Second, risk-adjusted announcement window returns are obtained by taking the residuals from a cross-sectional regression of raw announcement window returns on the estimated factor sensitivities. Even (odd) columns report results estimated with (without) six-digit GICS industry fixed effects. Regressions in columns (1) and (2) are estimated for the sample of staggered-board firms and columns (3) and (4) are estimates for the sample of firms without staggered boards. Cluster-robust standard errors, clustered at the six-digit GICS level, appear immediately below the coefficient estimates in parentheses. Levels of significance are indicated by $*, * *$, and $* * *$ for $10 \%, 5 \%$, and $1 \%$, respectively.

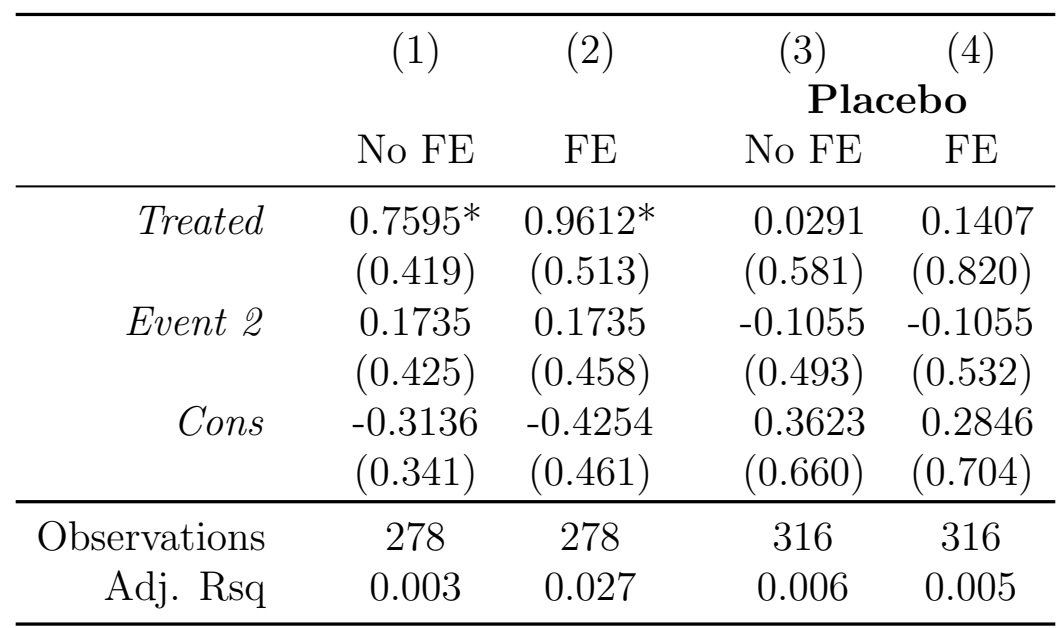




\section{Table II. Propensity Scores}

Table II reports the regression coefficients from logistic regressions of the treatment indicators on observable firm characteristics associated with a firm's takeover likelihood, as well as its likelihood to choose an annual shareholder meeting later in the calendar year. Treatment group definitions are as described in Section 4.1. Industry-adjusted Q $(Q)$ is defined as Tobin's Q less the GICS6 industry median, where $Q$ is defined as the market value of assets divided by the book value of assets where the market value of assets equals the book value of assets plus market value of common stock less the sum of the book value of common stock and balance sheet deferred taxes. Here, Ind-adjusted PPE/Assets (PPEEE) is defined as the ratio of plant, property, and equipment to total assets less the GICS6 industry median; Ind-adjusted Cash/Assets (Cash) is defined as the log of the ratio of cash to total assets less the GICS6 industry median; Size is defined as the log of market capitalization taken from the most recently available annual financial statements; Industry Takeover Intensity ( Takeover \%) is defined as the proportion of firms in the GICS4 industry that were acquired in calendar year 2009; Ind-adjusted Leverage (Leverage) is the ratio of long-term debt to assets less the GICS6 industry median; Ind-adjusted ROA (ROA) is defined as ROA less the GICS6 industry median, where ROA is defined as operating income divided by the book value of assets from the end of the previous fiscal year; and Top 10 Owners is defined as the total percentage of the equity holdings of the top 10 owners. Column (1) reports the estimated logistic coefficients and column (2) reports each variable's marginal effects (MFX) evaluated at the means. Levels of significance are indicated by $*, * *$, and $* * *$ for $10 \%, 5 \%$, and $1 \%$, respectively.

\begin{tabular}{ccc}
\hline & $(1)$ & $(2)$ \\
& & MFX \\
\hline$Q$ & -0.021 & -0.005 \\
PP\&E & $(0.12)$ & $(0.03)$ \\
& 0.912 & 0.223 \\
Cash & $(1.50)$ & $(0.37)$ \\
& -0.005 & -0.001 \\
Size & $(0.21)$ & $(0.05)$ \\
& $-0.429^{* * *}$ & $-0.105^{* * *}$ \\
Takeover \% & $(0.13)$ & $(0.03)$ \\
& $25.198^{* * *}$ & $6.172^{* * *}$ \\
Leverage & $(6.71)$ & $(1.66)$ \\
& -0.524 & -0.128 \\
ROA & $(0.96)$ & $(0.23)$ \\
& $2.632^{* * *}$ & $0.645^{* * *}$ \\
Top 10 Owners & $(0.99)$ & $(0.24)$ \\
& -0.014 & -0.004 \\
& $(0.01)$ & 0.00 \\
\hline Observations & 139 & 139 \\
Pseudo $R^{2}$ & 0.125 & 0.125
\end{tabular}




\section{Table III. Matched Sample Covariate Balance}

Table III reports the means of firm characteristics by treatment and control firms and the differences in means, as well as their statistical significance. Panel A reports the means for the unmatched sample of treatment and control firms. Panel B reports the differences in means in the propensity-score-matched sample. Panel $\mathrm{C}$ reports the differences in means in the propensityscore-matched sample where we also match each treated firm to a control firm within the same GICS4 industry. Levels of significance are indicated by *,**, and *** for $10 \%, 5 \%$, and $1 \%$, respectively.

Panel A: Unmatched Sample

\begin{tabular}{ccccc}
\hline & Treatment & Control & Diff & \\
\hline Propensity & 0.6236 & 0.4675 & 0.1560 & $* * *$ \\
$Q$ & 0.2954 & 0.5240 & -0.2285 & \\
PPEE & 0.0100 & -0.0034 & 0.0135 & \\
Cash & 0.0406 & -0.0095 & 0.0501 & \\
Size & 5.7922 & 6.7301 & -0.9379 & $* * *$ \\
Takeover \% & 0.0584 & 0.0463 & 0.0121 & $* * *$ \\
Leverage & 0.0702 & 0.0805 & -0.0103 & \\
ROA & 0.0105 & 0.0111 & -0.0006 & \\
Top 10 Owners & 39.9186 & 42.8912 & -2.9726 & \\
\hline
\end{tabular}

Panel B: Matched Sample

\begin{tabular}{crrrrr}
\hline & & \multicolumn{2}{c}{$m=1$} & \multicolumn{2}{c}{$m=2$} \\
& Treatment & Control & Diff & Control & Diff \\
\hline Propensity & 0.6236 & 0.6156 & 0.0079 & 0.6117 & 0.0119 \\
$Q$ & 0.2954 & 0.0351 & 0.2604 & 0.0806 & 0.2149 \\
PPEE & 0.0100 & 0.0139 & -0.0039 & 0.0199 & -0.0099 \\
Cash & 0.0406 & 0.0058 & 0.0348 & 0.0566 & -0.0160 \\
Size & 5.7922 & 5.7997 & -0.0075 & 5.5971 & 0.1951 \\
Delaware Inc & 1.0000 & 1.0000 & 0.0000 & 1.0000 & 0.0000 \\
Takeover \% & 0.0584 & 0.0585 & -0.0001 & 0.0544 & 0.0041 \\
Leverage & 0.0702 & 0.0360 & 0.0342 & 0.0510 & 0.0192 \\
ROA & 0.0105 & -0.0341 & 0.0445 & -0.0518 & 0.0623 \\
Top 10 Owners & 39.9186 & 39.5614 & 0.3572 & 36.7835 & 3.1351 \\
\hline
\end{tabular}


Table III Continued

Panel C: Matched Sample, by GICS4

\begin{tabular}{|c|c|c|c|c|c|c|c|}
\hline & \multicolumn{3}{|c|}{$m=1$} & & \multicolumn{3}{|c|}{$m=2$} \\
\hline & Treatment & Control & Diff & & Control & Diff & \\
\hline Propensity & 0.6236 & 0.6121 & 0.0115 & & 0.5987 & 0.0248 & \\
\hline$Q$ & 0.2954 & 0.4529 & -0.1574 & & 0.4419 & -0.1465 & \\
\hline PPEE & 0.0100 & 0.0244 & -0.0144 & & 0.0343 & -0.0243 & \\
\hline Cash & 0.0406 & 0.2356 & -0.1950 & & 0.2042 & -0.1636 & \\
\hline Size & 5.7922 & 5.7971 & -0.0050 & & 5.7971 & -0.0050 & \\
\hline Delaware Inc & 1.0000 & 1.0000 & 0.0000 & & 1.0000 & 0.0000 & \\
\hline Takeover \% & 0.0584 & 0.0564 & 0.0020 & & 0.0531 & 0.0053 & $*$ \\
\hline Leverage & 0.0702 & 0.0037 & 0.0665 & $* *$ & 0.0312 & 0.0389 & \\
\hline$R O A$ & 0.0105 & -0.0236 & 0.0341 & & -0.0245 & 0.0350 & \\
\hline Top 10 Owners & 39.9186 & 40.7487 & -0.8301 & & 39.2241 & 0.6945 & \\
\hline
\end{tabular}




\section{Table IV. Propensity Score Matching Estimates}

Table IV reports the propensity score bias-corrected matching estimates of the average treatment effect on treated firms (Treated). In column 1 (3), the propensity-score-matching estimators match, for each treated firm, $m=1(m=2)$ firms with the closest propensity scores. In column 2 (4), the propensity-score-matching estimators match, for each treated firm, $m=1$ $(m=2)$ firms with the closest propensity scores within the same GICS4 industry. Standard errors are heteroskedasticity-robust following Abadie and Imbens (2006) and are reported below the treatment effect estimates in parentheses. Panel A (B) is estimated for the sample of firms with (without) staggered boards. Observations report the total number of observations (treated and control) across two events. Levels of significance are indicated by ${ }^{a},{ }^{*},{ }^{* *}$, and ${ }^{* * *}$ for $11 \%$, $10 \%, 5 \%$, and $1 \%$, respectively.

Panel A

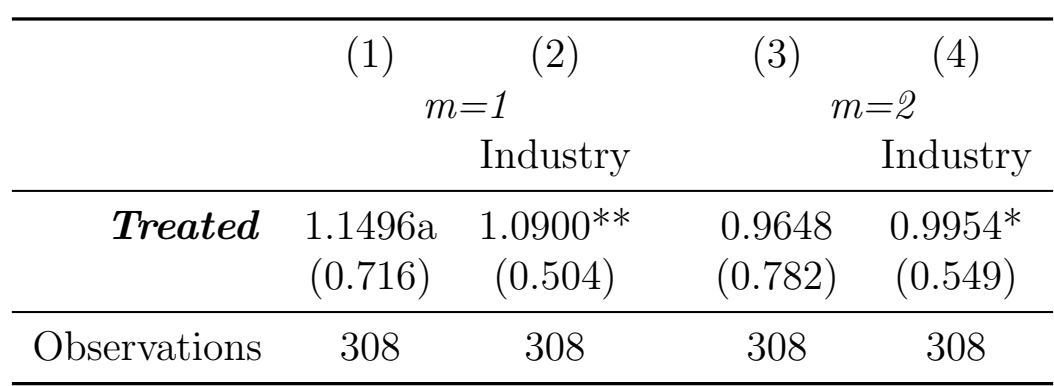

Panel B: Placebo

\begin{tabular}{rcccc}
\hline & $(1)$ & $(2)$ & $(3)$ & $(4)$ \\
& & $m=1$ & \\
& & \\
& & & \\
Industry & & Industry \\
\hline Treated & -1.1369 & -0.9012 & -0.2032 & -0.0542 \\
& $(1.102)$ & $(1.098)$ & $(0.781)$ & $(0.667)$ \\
\hline Observations & 304 & 304 & 304 & 304 \\
\hline
\end{tabular}




\section{Table V. Simulation over Non-event Days}

Table V reports summary statistics for the empirical bivariate distributions of simulated (over non-event days) OLS and propensity score estimates of average treatment effect for the treated. For each estimator, we report whether GICS6 industry fixed effects are included [or whether matching within GICS4 is performed for the case of propensity score (PS) estimates], our observed sample estimates on October 8 (Event 1) and November 23 (Event 2), the means and standard deviations of the simulated coefficients across the two non-event dates, and, finally, the likelihood of observing coefficients ( $p$-Value) larger than our observed Event 1 and Event 2 estimates from the simulated distribution. For example, the first row's $p$-Value represents the proportion of times we observe a pair of coefficients in the simulated OLS bivariate distribution that is larger than 0.6039 for Event 1 and smaller than -0.9151 for Event 2. Levels of significance are indicated by $* * *$, and ${ }^{* * *}$ for $10 \%, 5 \%$, and $1 \%$, respectively.

\begin{tabular}{lccccccccc}
\hline & & & & Mean & Std & Mean & Std & & \\
Estimator & Industry & Event 1 & Event 2 & Sim 1 & Sim 1 & Sim 2 & Sim2 & $p$-Value & \\
\hline (1) OLS & & 0.6039 & -0.9151 & -0.0897 & 0.7314 & -0.0386 & 0.5866 & 0.0093 & $* * *$ \\
(2) OLS & Yes & 0.8282 & -1.0941 & -0.1274 & 0.7744 & -0.0757 & 0.6301 & 0.0028 & $* * *$ \\
& & & & & & & & & \\
$(3)$ PS $(m=1)$ & & 1.9077 & -0.3914 & -0.1187 & 1.0137 & -0.1075 & 1.0158 & 0.0079 & $* * *$ \\
$(4)$ PS $(m=1)$ & Yes & 1.2550 & -0.9250 & -0.0552 & 1.1533 & -0.0554 & 1.1352 & 0.0181 & $* *$ \\
& & & & & & & & & \\
$(5) \mathrm{PS}(m=2)$ & & 1.2204 & -0.7092 & 0.0186 & 1.1264 & 0.0052 & 1.1272 & 0.0433 & $* *$ \\
$(6) \mathrm{PS}(m=2)$ & Yes & 1.0224 & -0.9685 & 0.0794 & 1.1449 & 0.0798 & 1.1544 & 0.0276 & $* *$ \\
\hline
\end{tabular}

